\title{
SENIORS IN THE POPOWICE HOUSING ESTATE IN WROCŁAW - SELECTED ISSUES
}

\author{
SENIORZY NA WROC ŁAWSKIM OSIEDLU POPOWICE \\ - WYBRANE ZAGADNIENIA
}

\author{
Barbara E. Gronostajska \\ professor \\ Author's Orcid number: 0000-0002-8425-220X \\ Politechnika Wrocławska \\ Wydział Architektury \\ Katedra Projektowania Architektoniczo-Konstrukcyjnego
}

\begin{abstract}
Contemporary block housing estates, apart from technical problems, face the new problem of an ageing society. These housing estates, built in the 1970s and 80 s, were inhabited primarily by young people, typically families with children. Many years later, the children, after gaining independence, left their family dwellings, leaving their ageing parents. Studies show that these housing estates are currently largely inhabited by seniors, who often live alone. This paper presents a study performed on the large-panel housing estates, Popowice, in terms of how it satisfies the needs of seniors. The paper also presents examples of apartment designs that sanction the needs of seniors, including seniors with special needs.
\end{abstract}

Key words: block housing estate, modernisation, large-panel technology.

\section{STRESZCZENIE}

Współczesne blokowiska, czyli osiedla budowane w technologii wielkiej płyty, borykają się z nowym problemem, jakim jest starzejące się społeczeństwo. Osiedla te, w latach 70. i 80. zamieszkały głównie osoby młode, najczęściej rodziny z dziećmi. Po latach dzieci, uzyskując samodzielność, opuściły rodzinne mieszkania, pozostawiając $w$ nich starzejących się rodziców. Osiedla te, obecnie, w dużym procencie zamieszkiwane są przez osoby starsze, często samotne. W najbliższej przyszłości pojawi się problem dostosowania mieszkań, przestrzeni publicznych, komunikacji do tej powiększającej się grupy społecznej. Artykuł prezentuje badania przeprowadzone na wrocławskim osiedlu - Popowice - pod kątem zaspokojenia potrzeb osób starszych. Pokazano także przykładowe rozwiązania mieszkań sankcjonujące potrzeby osób starszych, w tym niepełnosprawnych.

Słowa kluczowe: blokowisko, modernizacja, osoby starsze, wielka płyta. 


\section{INTRODUCTION — DEFINITION OF THE PROBLEM}

Large-panel buildings, or so-called panel block housing estates, have become a fixture of not only cities in Poland, but also of a considerable percentage of former Eastern Bloc countries. The monotonous walls of panel block housing estates welcome tourists entering both large cities (Warsaw, Lublin, Wrocław, Brno, Berlin, Dresden) as well as smaller ones (Rawicz, Oleśnica, Pilzno). They have become a sort of landmark of urban space and will probably keep this role for many years. We can ask the question as to the future of these housing estates. Will they be systematically demolished, with new development appearing in their place? Or perhaps, after repairs, shall they remain in the landscape as a testament to a past time? We are currently unable to clearly tell what the future of block housing estates might be. Analyses of foreign block housing estates show two possible ways in which to improve environments with large-panel development: demolition or modernisation. The Polish reality is quite clear. Large-panel housing estates, despite the increasing number of new apartments, are still inhabited by a large percentage of Poland's population (32\%), (Ludność Polski) and their residents report satisfaction with this environment. It should also be noted that analyses ${ }^{1}$ of contemporary housing designs do not paint them favourably in comparison to block housing estates, which are characterised by holistic and well-designed urban layouts, comprehensive services and comfortable, well-illuminated apartments. The monotony of their design, technical condition, finishing materials or neglected public spaces can certainly be seen as their disadvantages. This study was the result of an analysis of a series of reports that demonstrate that contemporary block housing estates are also facing the new problem of an ageing society. In the 1970s and 80 s, these housing estates were inhabited by young persons, typically families with children. After growing up and gaining independence, the children left the apartments, leaving their ageing parents behind. These housing estates are thus currently largely inhabited by seniors, who often live alone. Another argument in favour of studying this group of residents is the fact that Wrocław came third in terms of senior life expectancy, with $25 \%$ of its residents consisting of persons over sixty years of age.(Ranking) We can see the emergence of new problems associated with satisfying the needs of this group of tenants/residents. The study presented in this paper was conducted on one of Wrocław's large-panel block housing estates-Popowice-with a focus on the adaptation of such housing estates to the needs of seniors. The study was conducted in cooperation with Fundacja - Aktywny Senor, which has been active in this housing estate for many years, and the housing cooperative that manages the community. ${ }^{2}$

\section{SENIORS IN WROCŁAW'S SPACE-RESEARCH METHODS}

In 2019, 11,236 new apartments were handed over in Wrocław. The largest number of apartments - primarily in multi-family residential buildings - was built by real estate developers. The municipal company Towarzystwo Budownictwa Społecznego Wrocław Sp. z o.o. (TBS) (Raport) also operates on the housing market, yet its share in it is relatively small.

Some of the inhabitants of Wrocław (approx. 450,000) live in apartments in large-panel buildings. It should be noted that these apartments are priced on the secondary market at a comparable level to those built by real estate developers. Of note is also the fact that there is a lack of apartments for seniors on both the primary and secondary market. Meanwhile, according to a report from 2019, there is only one protected housing estate in all of Wrocław, ${ }^{3}$ along with sixteen legally operating care homes, retirement homes, nursing homes and social care homes.(Dom opieki) This offering is insufficient, which is why accommodation is sought outside of the city limits. Of note is also that residence in a social care home or nursing home is seen as a final solution in Polish conditions, opted for when a family is unable to care for their senior. In Western Europe, a model of retirement

\footnotetext{
${ }^{1}$ The author of the paper conducted studies of the quality of contemporary buildings offered by real estate development companies.

${ }^{2}$ As a part of this cooperation, the author obtained plans, designs, floor plans, information about residents and conducted workshops with residents.

${ }^{3} \mathrm{~A}$ protected apartment is a non-monetary social care benefit. Accommodation in such an apartment can be conferred upon a person who, due to a difficult life situation, age, disability or illness, requires aid in daily life, but does not require the services of a $24 \mathrm{~h}$ care unit. (Dla kogo)
} 
homes has emerged over the years that offers a more common form of residence for seniors. The Polish reality is different from that of the West. It should be highlighted that not all seniors end up in retirement homes. They are either too expensive or offer poor conditions. Most seniors do not want to leave their place of residence. This is why they should be allowed to live in their own housing environment for as long as possible. Numerous studies demonstrated that the necessary condition for maintaining fitness in advanced age is, among others, independence. Such independence is mostly provided by our own apartment, that we care for, maintain, embellish, and where we feel 'at home'.

This study includes an analysis of the existing state of the Popowice housing estate with a focus on seniors and accounts for architectural and urban solutions. The following analyses were performed: an urban and architectural analysis; a development morphology analysis; an analysis of circulation, recreational spaces and greenery; technical infrastructure and the technical condition of buildings; demography and apartment design. The findings of the analysis associated with the potential for the functioning of seniors in the space of the housing estate were collected and presented as a SWOT analysis. The study concludes with two application proposals 4 of adapting the housing estates to the needs of seniors that can be generalised and carried over to other solutions found in large-panel block housing estates. The research methods used in this study were based on a review of the literature, in situ field studies, building surveys, analyses of archival plans and designs of the housing estates, focus interviews and workshops.

\section{POPOWICE - URBAN AND ARCHITECTURAL ANALYSIS}

The area under analysis is located in the Fabryczna district. The area is located a certain distance away from the city centre, ca. $4-5 \mathrm{~km}$ from the Market Square and is in the immediate vicinity of the exit road towards Zielona Góra. The housing estate is delineated from the south by Legnicka Street, from the east by Starograniczna Street and a railway track, from the north by Popowicka Street and from the west by Wejherowska Street. The subject of the analysis includes properties with an area of $36 \mathrm{ha}(900 \mathrm{~m} \times 400 \mathrm{~m})$, inhabited by 15,000 people. The area is located west of the Old Town. It abuts housing estates and service and retail areas from the south, recreational areas from the north and post-industrial buildings adapted to various functions from the west. The development in the area under analysis had been levelled due to wartime operations, which is why designers did not have to incorporate the development into existing tissue. The housing estate was built from scratch on a site free of development and is entirely comprised of multi-family residential buildings and buildings that provide essential services to residents, i.e. retail pavilions, schools, kindergartens and a church (wikipedia).

Fig. 1. Popowice, map with a division of the housing estate into four areas under discussion and an area with dominant functions described in the legend (source: original work based on a map provided by Google Maps).

Ryc. 1. Popowice, mapa z podziałem osiedla na cztery omawiane obszary oraz obszarami o dominujących funkcjach opisanych w legendzie, (źródło: mapa Google).

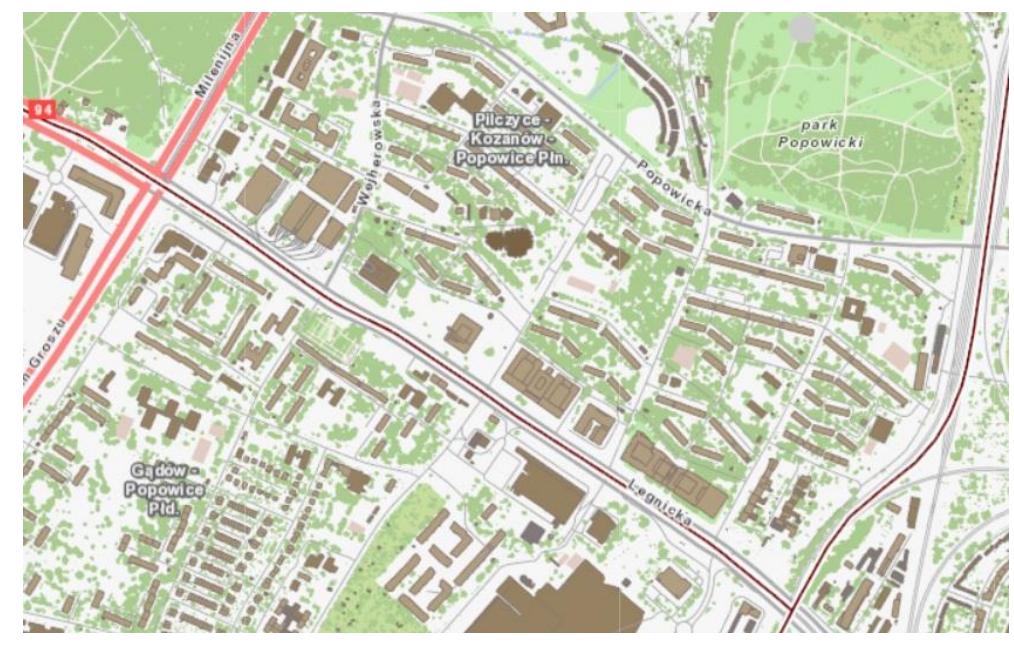

${ }^{4}$ One of the proposal is an original apartment design that was prepared by a group of students as a part of a design studio module taught by the paper's author. 
Recreational areas (semi-public spaces) located between buildings form a large share of the spatial structure of the housing estate. The housing estate's roads, which form a rather chaotic network, also constitute a relatively sizeable percentage. The site was observed to be well-equipped with public infrastructure (retail, healthcare, sports), located in the spaces between buildings.

Popowice is an attractive housing estate, as demonstrated by apartment prices. Despite being dwellings in so-called post-PRP block housing estates, the average apartment price is lower by only PLN 300-4005 when compared with apartments offered by real estate development companies. There are also cases where the prices are higher than the average price on the secondary market. Apartments located in the Popowice housing estates were selected for analysis.

Table 1. Comparison of prices for apartments located in the housing estates under study, original work based on WGN (original work based on https://adresowo.pl/mieszkania/wroclaw/popowice-l/)

\begin{tabular}{llcll}
\hline Location & Size & Number of rooms & Year of construction & Price per $\mathrm{m}^{2}$ \\
\hline Popowicka Street & $54 \mathrm{~m}^{2}$ & 3 & 1980 & $7375 / 399000$ \\
\hline Białowieska Street & $34 \mathrm{~m}^{2}$ & 2 & 1980 & $9700 / 330000$ \\
\hline Wejherowska Street & $64 \mathrm{~m}^{2}$ & 3 & 1980 & $7800 / 499000$ \\
\hline Niedźwiedzia Street & $41.5 \mathrm{~m}^{2}$ & 2 & 1980 & $8800 / 36500$ \\
\hline Jelenie Street & $42 \mathrm{~m}^{2}$ & 2 & 1980 & $9700 / 404000$ \\
\hline
\end{tabular}

Based on the secondary-market apartment price analysis presented above, it can be concluded that the prices were highly similar to primary-market prices - those offered for apartments built by real estate developers. The cause of this attachment to large-panel technology displayed by Polish citizens is worth exploring, as the general assessment of housing estates built using it are completely different.

\subsection{Development morphology}

The housing estate was designed by W. Molicki (M. Molicka, W. Molicki ...). The complex's spatial structure is dominated by multi-family development. It includes medium-height buildings - with three to five storeys - and tall buildings - with eleven storeys - built using large-panel technology, with additional thermal insulation applied to them around twenty-five years ago. The fragment under analysis is easily accessible, it has a network of paths along access roads to the housing estate. The area of the part of the housing estate under analysis has a compact, rectangular, elongated plan, divided by Rysia, Białowieska and Niedźwiedzia streets into four sections (fig. 1) with a complicated urban layout caused by the irregular placement of buildings at different angles. This 'jagged' layout causes chaos, which today results in, among other things, difficulties in finding a specific address. The buildings face south with their balconies, while their simple facades face north. Diagonal, irregular balconies that deal away with the monotony of large-panel structural systems are distinctive for the housing estate. The layout of buildings was designed so that every apartment can have access to a sufficient amount of daylight. Hence, there is a considerable amount of space between the apartment blocks, which is currently seen as especially valuable to children, the youth and seniors. 

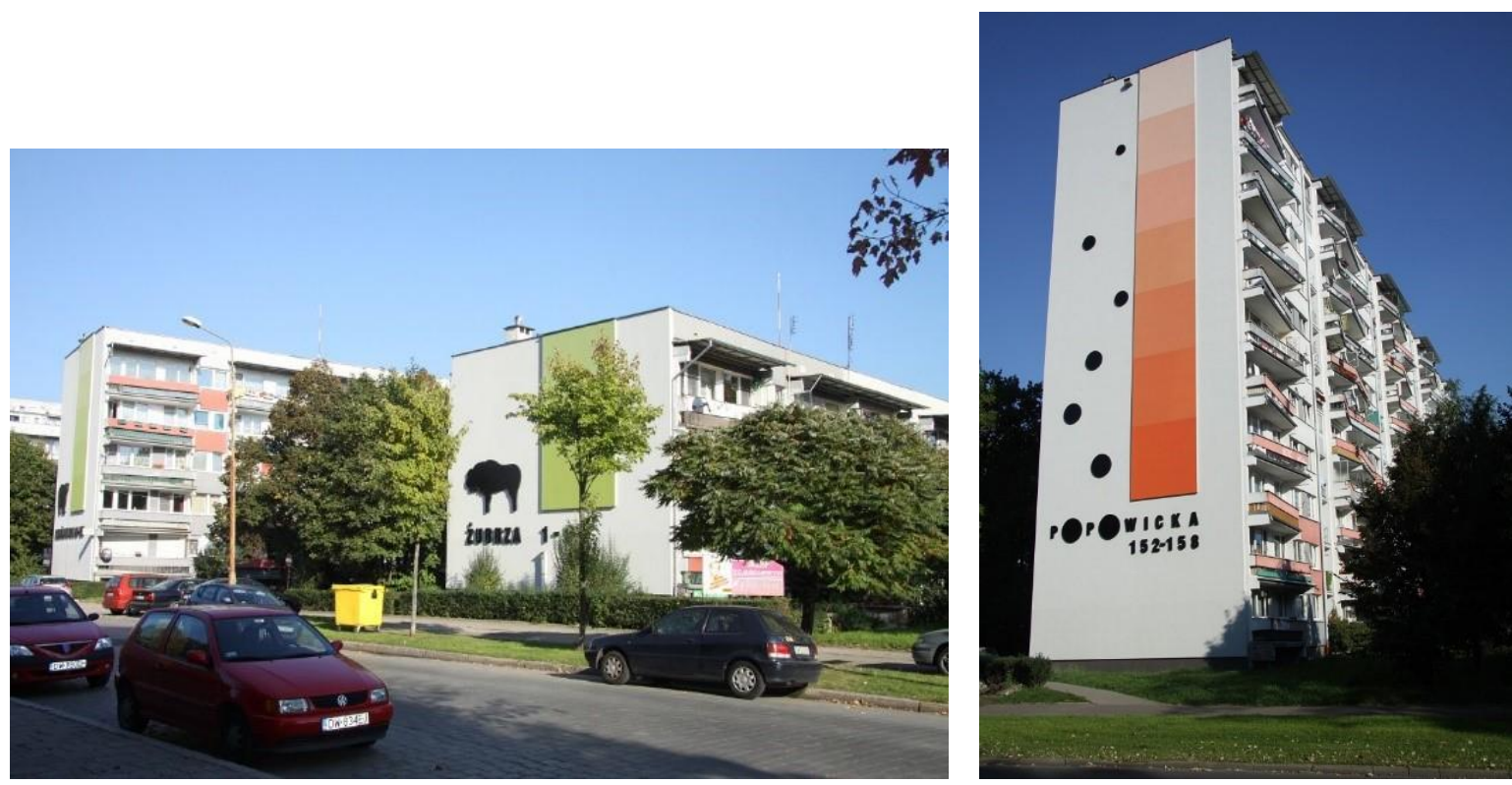

Fig. 2. Popowice. View of the modernised side walls of the housing estate's buildings, with visual information displaying Street names and postal numbers, (source: original photo).

Ryc. 2. Popowice. Widok osiedla na zmodernizowane ściany szczytowe, z informacją wizualną obejmująca nazwy i numery ulic, (źródło: fot. autor)

\subsection{Circulation}

The area of the Popowice housing estate has good circulation linkages with the city centre and other parts of the city. It is located near a major exit route from Wrocław, near which there is a comprehensive network of public transport. Access to the centre and from other city districts is also provided by public transport: buses and trams. The Mikołajów Train Station, whose renovation was recently completed, is located nearby, in addition to the Popowice Station, which abuts the housing estates and is now sporadically used, but is to see greater traffic after a planned renovation, as it is intended to serve as a railbus stop, which operates very efficiently across the agglomeration. ${ }^{6}$

The housing estate is located near to two bicycle trails. One follows Popowicka Street, while the other follows Legnicka Street. The housing estate is also crossed by an alternative bicycle trail. It runs through the middle of the estate, following Bobrza and Jelenia streets. All of the major bicycle trails lead along the east-west direction, while the number of north-south routes is limited.

In most cases, pedestrian paths are not adapted to the needs of persons with special needs and seniors: they have curbs and uneven surfaces. Only pedestrian crossings were found to have appropriate depressions without curbs.

The housing estates is equipped with parking spaces in the form of properly marked spaces along access streets, as well as larger parking lots with multiple spaces. The number of parking spaces is insufficient relative to the residents' needs, which can be felt particularly strongly in the areas with greater development density, mainly in the vicinity of eleven-storey buildings. The lack of a sufficient number of parking spaces results in improper parking in areas not intended for this purpose (lawns, pedestrian paths).

\footnotetext{
${ }^{6}$ Rapid municipal railway transport plays a significant role, connecting different fragments of the city with areas around it.
} 

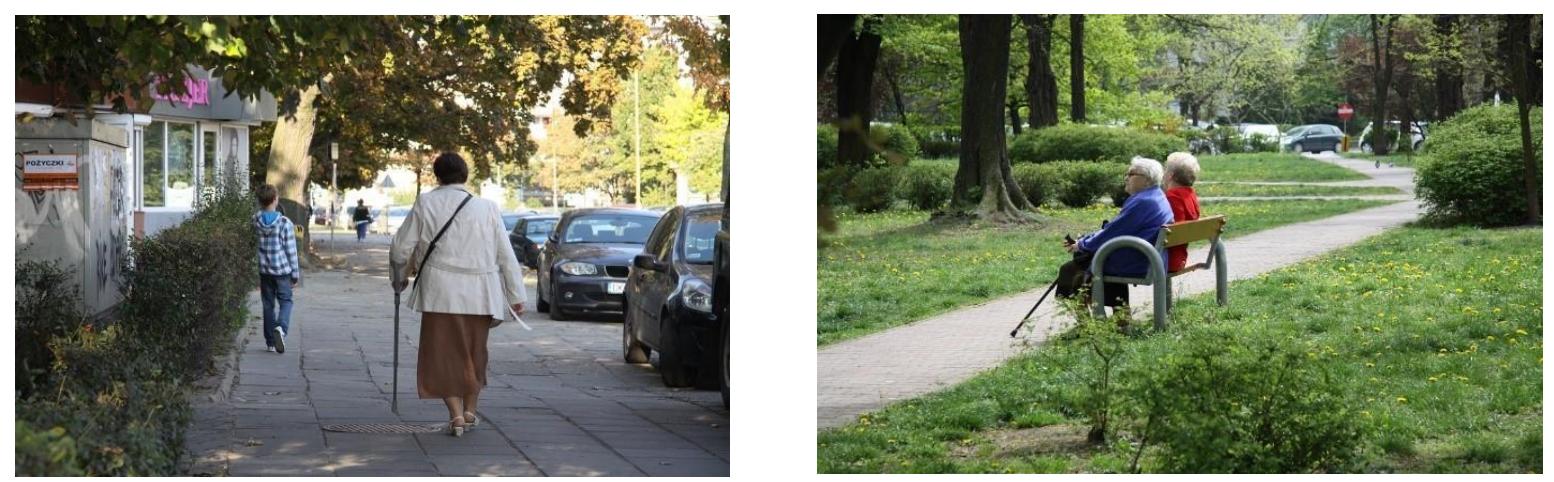

Fig. 3. Popowice. View of the pedestrian paths that cross through the housing estate, with a visible predominance of seniors engaging in recreation (source: original photo).

Ryc. 3. Popowice. Widok osiedla na ciągi piesze, poprowadzone przez osiedle, wyraźnie widać przewagę osób starszych korzystających z rekreacji (źródło: fot. autor).

The housing estate features dedicated and marked parking spaces for persons with special needs. They are typically located near entrances to stairwells.

No dedicated spaces for bicycles were observed, which can be seen as the cause of residents leaving them everywhere they can: leaning against trees, benches and in front of stairwells.

\subsection{Recreational spaces and greenery}

A large number of recreational spaces is a characteristic trait of large-panel housing estates. The analysis of the area showed that the housing estate possesses a range of diverse recreational spaces (fig. 3) and green areas, which include:

- Spaces in semi-public areas, located between buildings - generally accessible spaces intended for sports, recreation and playgrounds that are even used by residents who live in more distant areas of the estate.

- Areas in public spaces - largely located outside of the housing estate's borders, at a distance of around $800 \mathrm{~m}$ from places of residence. They include freely accessible areas in the form of parks and greens, i.e. Park Zachodni, Park Popowicki and a green square near a local church.

Play areas are well-maintained. Most were found to have undergone a general modernisation, with their old equipment replaced, making them colourful and varied. The spaces between buildings also include sports areas with a broad offering, e.g. tennis courts, basketball and volleyball courts, as well as a cross hill near Rysia Street.

The housing estate includes numerous places for rest (benches, seats), which are particularly essential to older people who use passive forms of recreation.

The housing estate possesses a wealth of greenery, which typically comprises tall trees and bushes. Their level of maintenance is highly varied and depends on the fragment to which a given section of greenery belongs to. The situation is similar with pedestrian paths, many of which cross the housing estate along the north-south and east-west direction. The quality of pedestrian paths and their adaptation to the needs of seniors varies. The buildings have frontal gardens near the entrances that are neglected and feature random greenery. However, residents establish private green spaces near balconies, which feature very pleasant plant cover.

\subsection{Social infrastructure}

Social infrastructure is an important aspect of the analyses in the context of seniors. The Popowice housing estate possesses a large number of service establishments both within its limits and in its vicinity. When analysing the housing estate's social infrastructure, it should be stated that: 
- The housing estate is well-equipped with a range of buildings, particularly educational facilities, which can be used by seniors, such as gymnastics halls and a school swimming pool.

- There is a large number of retail establishments.

- The housing estate is located near SEKTOR $3,{ }^{7}$ which is an area in which Fundacja Aktywny Senior (Active Senior Foundation) operates, and which can be and is used by older residents of the housing estate.

- There is a lack of gastronomic services - to access them, one must travel considerable distances to other parts of the housing estate.

- Not all services are accessible to seniors and persons with special needs. Some service establishments are located above the ground floor and are only accessible via stairs (no ramps, lifts, platforms).

\subsection{Technical condition of buildings}

The technical condition of the buildings as seen during the study was average. The residential buildings were built using the Wrocław Large-panel Technology:

- All buildings are heated by the municipal grid - and are supplied with central heating, domestic water and gas.

- Some of the apartments are air-conditioned. However, these are private ventures and airconditioning units were seen to be installed on balconies and facades, disrupting the purity of the facade.

- 5-storey buildings are not equipped with lifts, while taller, eleven-storey ones are.

- The buildings were subjected to thermal retrofitting quite some time ago and only an additional layer of $5 \mathrm{~cm}$ was of styrofoam was used.

- The colour scheme of the buildings and their side walls were given a visual makeover, (see fig. 2).

- Balconies were found to be in very poor condition, while plasters - exposed to atmospheric conditions for years - were missing in some spots and showed cracks.

- Some stairwell entrances were found to be inaccessible to special needs persons due to sills and stairs.

\subsection{Apartment design}

The housing estate offers apartments that are varied in terms of floor area, ranging from singleroom to five-room apartments. 8 There are two types of buildings in the estate: eleven-storey stairwell-type buildings and five-storey stairwell-type buildings with two or three apartments per storey. The buildings were designed via a varied configuration of several types of apartments and the introduction of a variable number of segments (stairwells). Despite the fact that the housing estate had been designed and built using industrial technology, the apartment structure was observed to be varied. Every storey features two or three apartments. The following types of large apartments that consist of rooms, a kitchen, a hall, a bathroom and a toilet can be distinguished in the estate: ${ }^{9}$

- One five-room apartment - $78.80 \mathrm{~m} 2$,

- Three-room apartments with varying amounts of floor area $-50.50 \mathrm{~m} 2,53.50 \mathrm{~m} 2,57 \mathrm{~m} 2,58$ $\mathrm{m} 2,59.50 \mathrm{~m} 2$ and $65.50 \mathrm{~m} 2$,

- four-room apartments with a floor area of $63 \mathrm{~m} 2$.

\footnotetext{
7 The Wrocław Center for Supporting Non-Governmental Organizations Sector 3 has been operating since April 2007. It is run by the Foundation for Supporting NGOs "UMBRELLA" in the form of a public task and is financed from the budget of the Wrocław Commune. In the period from January 1, 2020 to December 31, 2022, we are implementing the project "Promotion of the Wrocław Center for Supporting Non-governmental Organizations Sector 3". (O centrum)

${ }^{8}$ There is only one apartment in the housing estate that is the effect of a merger of two other apartments.

${ }^{9}$ Dane uzyskane od zarządcy spółdzielni. Data was obtained from the housing cooperative-the property manager.
} 
Medium-sized apartments include:

- Two-room apartments with floor areas of $49.50 \mathrm{~m} 2$ and $50.50 \mathrm{~m} 2$.

While small apartments included:

- Two-room apartments with the following floor areas: $41.50 \mathrm{~m} 2,41 \mathrm{~m} 2,40.50 \mathrm{~m} 2,39 \mathrm{~m} 2$ and 33 $\mathrm{m} 2$.

- Single-room apartments with a floor area of $23.50 \mathrm{~m} 2$.

The apartments have living rooms with a similar floor area of around $14.50 \mathrm{~m} 2$, which means they do not meet currently applicable regulations (Ordinance...), ${ }^{10}$ while bedrooms have minimum floor areas of between 7 and $9 \mathrm{~m} 2$. The larger apartments feature bathrooms and independent toilets.
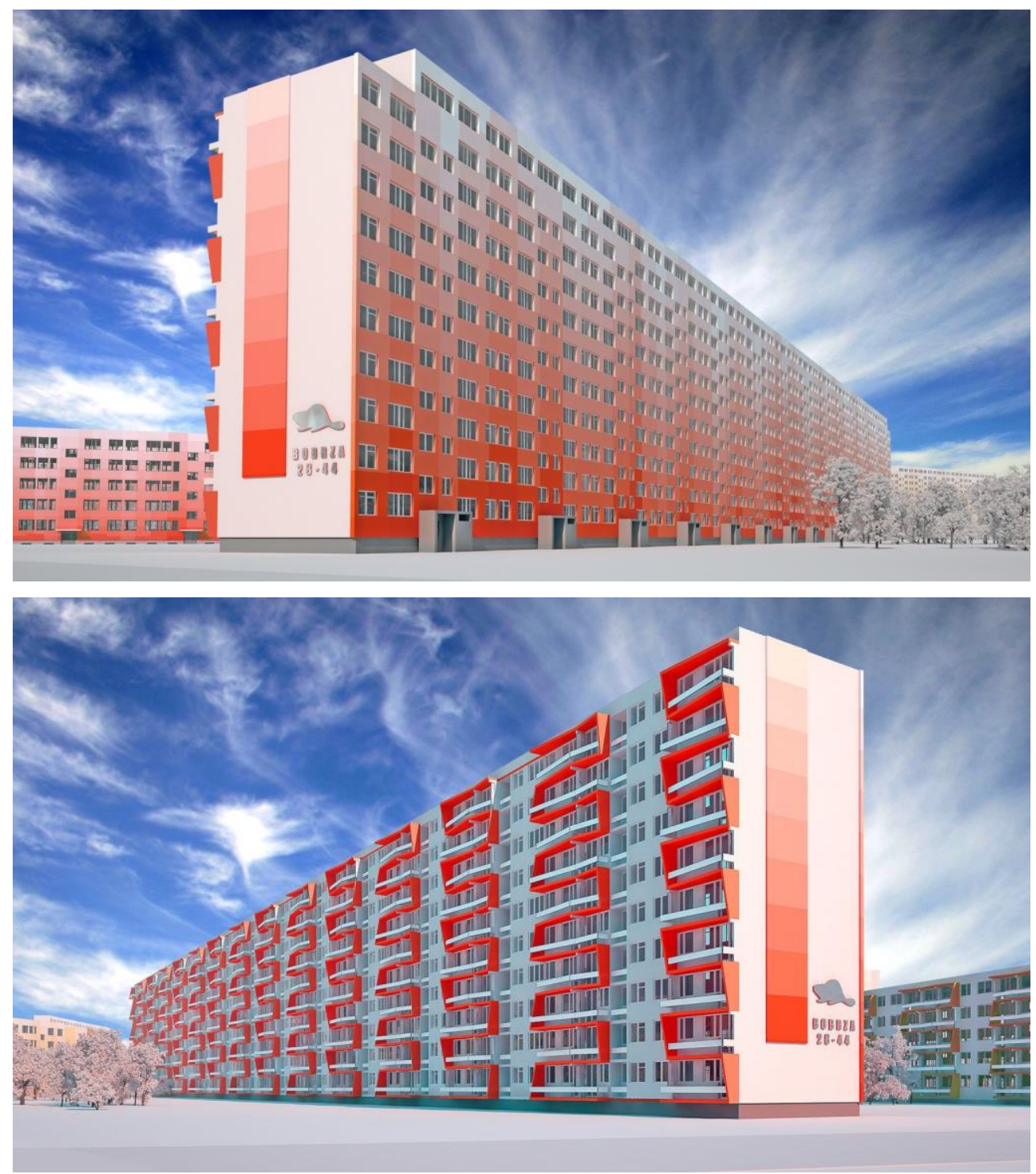

Fig. 4. A propo-sal to modernize the elevation of a high building - vi-sualization, north and southern elevation. Source: (Wrocław)

Ryc. 4. Propozy-cja modernizacji elewacji budynku wysokiego - wi-zualizacja, elewa-cja północna i południowa Źródło: (Wrocław)

10 ‘ 94, pt 2. At least on room in a dwelling must have a floor area no smaller than $16 \mathrm{~m}^{2}$. (Rozporządzenie). 


\subsection{Demography}

Based on the collected materials and studies performed, it can be stated that persons above sixty years of age formed a significant share of the housing estate's population. In this section, they were found to make up around $70 \%$ of the population. ${ }^{11}$ They are persons who have been inhabiting the housing estate since its construction. They moved into their apartments as young married couples and have remained in them until the present. At the start of the twenty-first century, after 2006, relatively many young people appeared. This was associated with the initiation of the new RnS financial programme. The programme enabled families to receive preferential loans. During this period, many young people bought apartments in the housing estate that were relatively small (inexpensive), while the proximity of recreational areas and educational services makes it ideal for young married couples with children. They are visible in recreational areas.

\section{SENIORS IN THE SPACE OF THE POPOWICE HOUSING ESTATE - ANALYSIS CONCLUSIONS}

After performing an analysis of the existing state of the housing estate, conclusions were formulated in the form of a SWOT analysis, presented in table 2 . They are associated with the potential functioning of seniors and persons with special needs in the space of the estate.

Table 2. SWOT analysis of the large-panel housing estates in terms of their adaptation to the needs of seniors (source: original work)

\begin{tabular}{|c|c|c|}
\hline & Strengths & \\
\hline Urban & Architectural and technical & Socio-economic \\
\hline $\begin{array}{l}\text { Good circulatory linkages with the } \\
\text { city }\end{array}$ & Apartments equipped with amenities & Relatively low maintenance costs \\
\hline Large number of essential services & $\begin{array}{l}\text { Apartment functional design - layout- } \\
\text { based }\end{array}$ & $\begin{array}{l}\text { Familiarity with neighbours and close } \\
\text { neighbourly ties }\end{array}$ \\
\hline $\begin{array}{l}\text { Proximity of recreational and sports } \\
\text { areas }\end{array}$ & $\begin{array}{l}\text { Apartment size - typically suitable for } \\
\text { married couples or persons who live } \\
\text { alone (two- and three-room apartments) }\end{array}$ & $\begin{array}{l}\text { Possibility of obtaining funding from } \\
\text { European Union funds }\end{array}$ \\
\hline \multicolumn{3}{|l|}{ A large amount of greenery } \\
\hline \multicolumn{3}{|l|}{ Considerable amount of space } \\
\hline \multicolumn{3}{|l|}{ Good housing estate infrastructure } \\
\hline & Weaknesses & \\
\hline & $\begin{array}{l}\text { Stairwells without lifts in 5-storey build- } \\
\text { ings }\end{array}$ & $\begin{array}{l}\text { Lack of funds for renovation and mod- } \\
\text { ernisation }\end{array}$ \\
\hline $\begin{array}{l}\text { No dedicated bicycle circulation } \\
\text { solutions }\end{array}$ & $\begin{array}{l}\text { Entrances to stairwells without access } \\
\text { ramps - barriers }\end{array}$ & $\begin{array}{l}\text { Flight of young people from housing } \\
\text { estates of this type }\end{array}$ \\
\hline $\begin{array}{l}\text { Lack of a sufficient number of } \\
\text { parking spaces }\end{array}$ & $\begin{array}{l}\text { Lack of seating and bicycle stands near } \\
\text { stairwell entrances }\end{array}$ & $\begin{array}{l}\text { Residents accustomed to their place of } \\
\text { residence }\end{array}$ \\
\hline $\begin{array}{l}\text { Lack of a sufficient number of } \\
\text { dedicated parking spots for per- } \\
\text { sons with special needs }\end{array}$ & $\begin{array}{l}\text { Apartments are not adapted to persons } \\
\text { with special needs (wheelchair-bound } \\
\text { persons) }\end{array}$ & $\begin{array}{l}\text { The housing estates are primarily in- } \\
\text { habited by seniors }\end{array}$ \\
\hline \multirow[t]{2}{*}{$\begin{array}{l}\text { Greenery in various states of ne- } \\
\text { glect }\end{array}$} & No communal spaces in buildings & $\begin{array}{l}\text { Apartments are rented to students for } \\
\text { short periods of time }\end{array}$ \\
\hline & No private gardens & \\
\hline
\end{tabular}

${ }^{11}$ Data obtained from the housing cooperative that manages the estate. 


\begin{tabular}{|c|c|c|}
\hline & Opportunities & \\
\hline $\begin{array}{l}\text { Housing environment is friendly to } \\
\text { seniors }\end{array}$ & $\begin{array}{l}\text { Apartments are adapted to seniors after } \\
\text { modernisation }\end{array}$ & $\begin{array}{l}\text { Obtainment of funds from EU, municipal } \\
\text { or target projects }\end{array}$ \\
\hline \multirow[t]{2}{*}{$\begin{array}{l}\text { Development density increases via } \\
\text { the construction of buildings dedi- } \\
\text { cated to seniors }\end{array}$} & $\begin{array}{l}\text { Apartments on upper stories can be } \\
\text { made accessible via building lifts, plat- } \\
\text { forms and ramps }\end{array}$ & \\
\hline & Threats & \\
\hline $\begin{array}{l}\text { The introduction of buildings built } \\
\text { by real estate development com- } \\
\text { panies into the housing estates } \\
\text { (gated communities) can lead to } \\
\text { uncontrolled development densifi- } \\
\text { cation }\end{array}$ & $\begin{array}{l}\text { Buildings that are not renovated and that } \\
\text { remain unadapted to changing needs will } \\
\text { deteriorate and decay }\end{array}$ & $\begin{array}{l}\text { Loneliness and solitude caused by a } \\
\text { lack of contact with the surroundings }\end{array}$ \\
\hline $\begin{array}{l}\text { New projects that come at the cost } \\
\text { of social spaces can devalue rec- } \\
\text { reational, sports and play areas }\end{array}$ & & $\begin{array}{l}\text { Housing estates can become slums } \\
\text { inhabited by the lowest-status social } \\
\text { groups }\end{array}$ \\
\hline
\end{tabular}

Analyses indicate that the internal space of the housing estate, assuming minor reparatory measures, is in a satisfactory condition in terms of the needs of seniors. During the study, a series of meetings/workshops was organised with seniors who inhabit the housing estate, in addition to focus interviews during which the residents could express their opinions about the manner and form of housing in the case of either full or partial loss of autonomous functioning. The effect of this survey was not surprising, as all respondents opted for remaining in their current place of residence, only highlighting a need for external aid in everyday activities. Meanwhile, in the case of more serious cases of disability, they expressed a desire to remain in a familiar environment, i.e. the space of the housing estate, but in a different building, such as a retirement home located near their place of residence.

The following two solutions were proposed in response to this:

- Adapting apartments to the needs of seniors, including seniors with special needs.

- Adapting one of the buildings into a retirement home.

\subsection{Adaptation of apartments to the needs of seniors, including seniors with special needs}

Analyses of existing development and other housing estates/buildings that had undergone thorough modernisation indicated that there exists a potential for remodelling both stairwells and apartments to better suit the needs of seniors, including seniors with special needs. The least costly solutions can be applied in tall, eleven-storey buildings, which were found to already be equipped with lifts that nevertheless start on the ground floors. A movable platform that would connect the ground level with the ground floor is a simple solution that can be used here. More complicated solutions would have to be applied in the case of five-storey buildings, which are not equipped with lifts. The only option here is to remodel stairwells to introduce independent lifts.

However, the key matter is the adaptation of apartments to the needs of seniors, including seniors with special needs. The structural systems applied in the construction of the buildings under study enable minor wall relocation and certain variants of remodelling functional layouts. Bathrooms and toilets would have to be adapted first by increasing space needed for movement. It is important to correctly design kitchens via appropriate furniture arrangements and creating space for movement. The illustration below shows a sample design of an apartment's interior adapted to a person with special needs. 

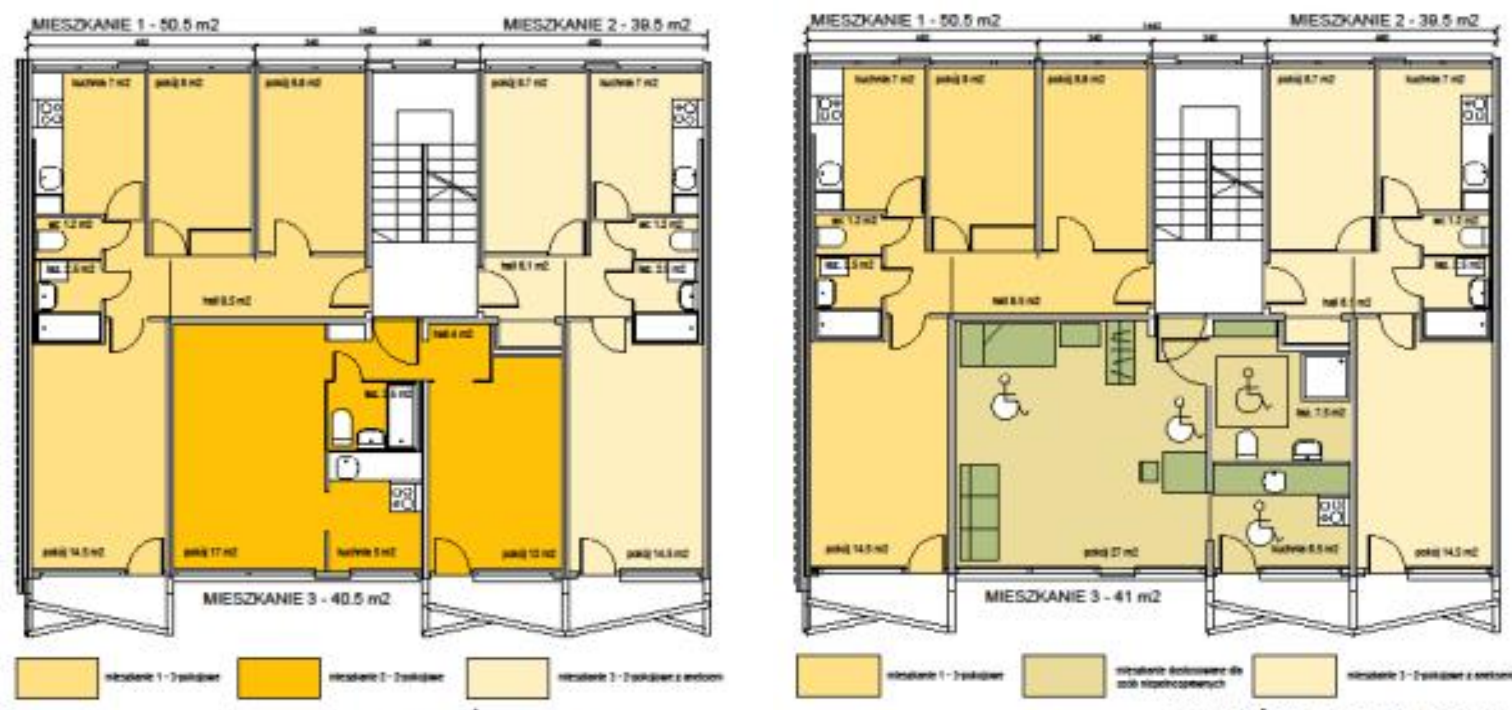

NIEDŹWIEDZIA 53-61

NIEDŹWIEDZIA 53-61

Fig. 5. Popowice, five-storey stairwell-type bilding, 53-61 Niedźwiedzia Street, common flor plan, (on the left) existing state with three apartments with two and three rooms, (on the right) an original proposal of the apartment's design, adapted to persons with special needs, (source: original work).

Ryc. 5. Popowice, budynek 5-kondygnacyjny, klatkowy, ulica Niedźwiedzia 53-61, rzut kondygnacji powtarzalnej, (po lewej) stan istniejący z 3 mieszkaniami 2 i 3-pokojowymi j, (po prawej) autorska propozycja rozwiązanie mieszka-nia, przystosowanego do potrzeb osoby niepełnosprawnej, (źródło: opr. autor)

\subsection{Adaptation of one of the buildings into a retirement home}

In response to the conclusions presented above, this section features a students' proposal of adapting one of the eleven-storey buildings (fig. 6) into a retirement home. The assumption behind the design was the modernisation of the building and adapting it to the needs of seniors $(70+),{ }^{12}$

Fig. 6. Sheet no. 1 of the Retirement home design, to be located on the housing estate of Popowice, authors: Paweł Floryn, Łukasz Sokołowski.

Ryc. 6. Plansza $\mathrm{nr} 1 \mathrm{z}$ projektem „Dom seniora" na osiedlu Popowice, autorzy: Paweł Floryn, Łukasz Sokołowski.

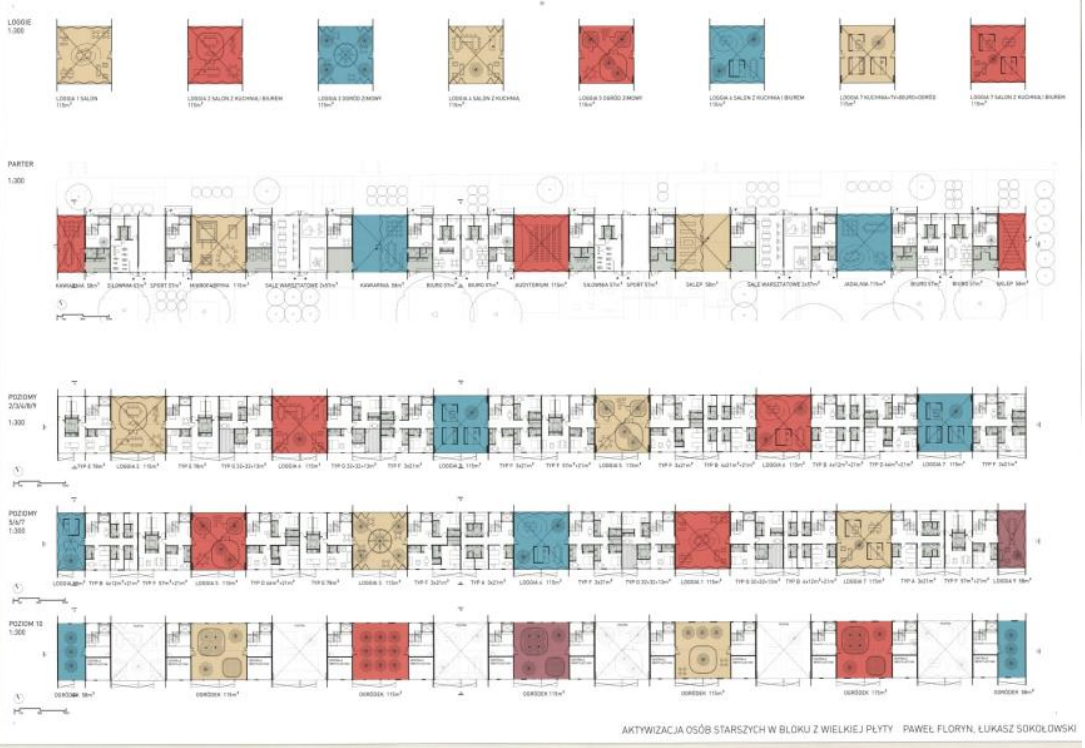

${ }^{12}$ The design was prepared as a part of the elective module Design for seniors. Authors: Paweł Floryn, Łukasz Sokołowski, supervisor: Barbara Gronostajska. 


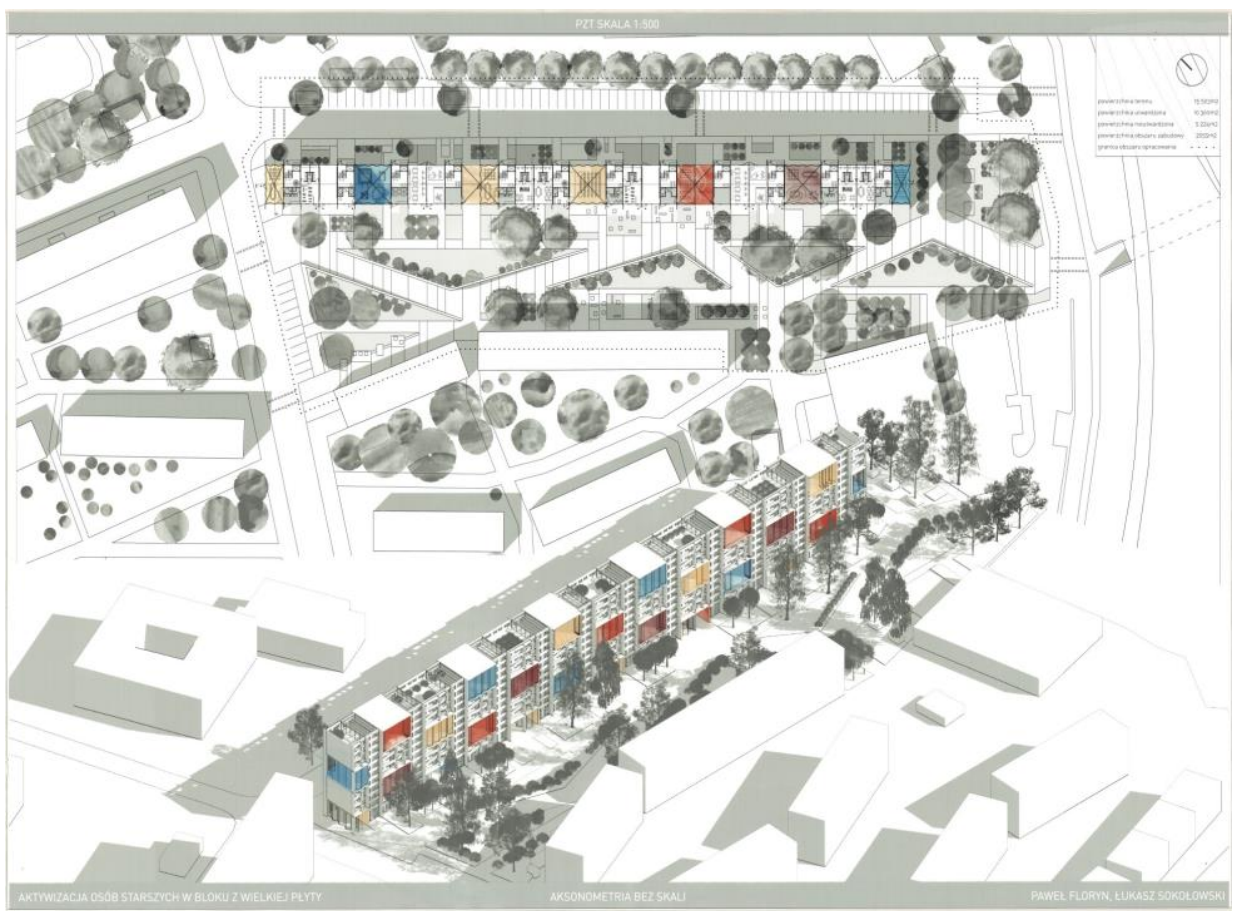

Fig. 7. Sheet no. 2 of the Retirement home design, to be located in the housing estate of Popowi-ce, authors: Paweł Floryn, Łukasz Sokołowski. Ryc. 7. Plansza $\mathrm{nr} 2$ z projektem „Dom seniora" na osiedlu Popowice, autorzy: Paweł Floryn, Łukasz Sokołowski.

The authors of the design presented 8 functionally varied community modules with a floor area of $115 \mathrm{~m} 2$, (fig. 6).

The apartments that are to satisfy essential housing needs were designed in a similar modular manner. Single, two- and three-room apartments, each equipped with a loggia or a balcony. The apartments were intentionally designed not to be excessively large, as many activities, such as work, social gatherings and cooking, were intended to take place in common areas. A service section, stores, coffee shops, rehabilitation facilities were traditionally placed on the ground floor and made accessible from ground level, (fig. 7).

\section{CONCLUSIONS}

With certain financial investment, it is possible to improve housing quality, which can be performed via a series of measures that make the life and functioning of seniors, including seniors with special needs, much easier. These measures can be divided into a number of groups:

- Adaptation - e.g. of apartments to new needs,

- Adaptive reuse - e.g. converting buildings into homes for seniors,

- Densification - introducing day care and 24h centres for seniors,

- Cohousing - adapting unused rooms into common spaces suitable to the needs of seniors.

To summarise the presented study in the context of meeting criteria of adaptation to the needs of seniors and persons with special needs, it is the spaces of the housing estate that were rated the highest, as they were found to be adapted to the needs of this social group to the greatest degree. Public transport was rated second-highest. It is largely dependent on municipal policy and was found to be designed relatively correctly in the locations under study. Apartment solutions were rated the lowest, as they were found to be incompatible with the needs of seniors. However, there exists a tangible possibility of introducing reparatory measures intended to adapt the housing estates to the needs of seniors, including seniors with special needs. However, large-scale cooperation between senior care centres, property managers and municipal authorities is required. 


\section{SENIORZY NA WROC ŁAWSKIM OSIEDLU POPOWICE - WYBRANE ZAGADNIENIA}

\section{WPROWADZENIE - ZDEFINIOWANIE PROBLEMU}

Budynki z wielkiej płyty tzw. blokowiska wpisały się na stałe w krajobraz nie tylko polskich miast, ale również w dużym procencie państw byłego „bloku wschodniego” Monotonne ściany blokowisk witają turystów wjeżdżających, zarówno do dużych miast (Warszawa, Lublin, Wrocław, Brno, Berlin, Drezno), jak i mniejszych (Rawicz, Oleśnica, Pilzno). Stały się one swego rodzaju landmarkami przestrzeni miejskiej i prawdopodobnie będą nimi jeszcze przez wiele lat. Można sobie zadać pytanie, jaka jest przyszłość tych osiedli. Czy będą one systematycznie burzone, a na ich miejscu pojawi się nowa zabudowa? A może, po działaniach naprawczych, pozostaną w krajobrazie, jako świadek minionej epoki? Nie jesteśmy w stanie jednoznacznie przewidzieć przyszłości blokowisk. Analizy zagranicznych osiedli z wielkiej płyty ukazują dwie możliwe drogi poprawy środowiska z zabudową wielkopłytową: wyburzenie lub modernizacja. Polskie realia są dość klarowne. Osiedla z wielkiej płyty, pomimo rosnącej liczby nowych mieszkań, wciąż zamieszkiwane są przez wysoki odsetek ludności Polski (32\%) (Ludność Polski), a mieszkańcy środowisko to bardzo sobie chwalą. Warto również dodać, że analizy ${ }^{13}$ współczesnych rozwiązań zabudowy mieszkaniowej wcale nie wypadają dużo korzystniej w porównaniu z blokowiskami, które charakteryzują się kompleksowo, dobrze rozwiązaną urbanistyką, pełnym wyposażeniem w usługi oraz wygodnymi, dobrze doświetlonymi mieszkaniami. Z pewnością wadą jest monotonia rozwiązań, stan techniczny, materiały wykończeniowe, czy zaniedbane przestrzenie publiczne. Podjęte badania były wynikiem analizy szeregu opracowań, które pokazują, że współczesne blokowiska borykają się również z nowym problemem, jakim jest starzejące się społeczeństwo. Osiedla te w latach 70. i 80. zamieszkiwały osoby młode, najczęściej rodziny z dziećmi. Dzieci po uzyskaniu samodzielności opuściły mieszkania, pozostawiając $w$ nich starzejących się rodziców. Tak więc osiedla te $w$ dużym procencie zamieszkiwane są obecnie przez osoby starsze, często samotne. Dodatkowym argumentem, przemawiającym za potrzebą zajęcia się tą grupą mieszkańców jest fakt, że Wrocław zajął 3 miejsce pod względem długości życia osób starszych, przy czym $25 \%$ mieszkańców to osoby powyżej 60 roku życia (Ranking). Pojawiają się zatem nowe problemy związane z zaspokojeniem potrzeb właśnie tej grupy lokatorów/mieszkańców. Przedstawione w artykule badania prowadzone były na jednym z wrocławskich osiedli z wielkiej płyty - Popowice - pod kątem przystosowania ich do potrzeb osób starszych. Prowadzone były we współpracy z Fundacją - Aktywny Senior, która od lat działa na tym osiedlu oraz spółdzielnią mieszkaniową, zarządzającą osiedlem ${ }^{14}$.

\section{SENIORZY W PRZESTRZENI WROC ŁAWIA - METODA BADAWCZA}

W 2019 roku we Wrocławiu oddano do użytku 11236 nowych mieszkań. Najwięcej mieszkań przede wszystkim w budynkach wielorodzinnych - powstało $w$ ramach budownictwa deweloperskiego. Na rynku mieszkaniowym działa również spółka miejska Towarzystwo Budownictwa Społecznego Wrocław Sp. z o.o. (TBS) (Raport), której udział w rynku mieszkaniowym jest stosunkowo mały.

Część mieszkańców Wrocławia (ok. 450 tys.) zamieszkuje mieszkania w budownictwie z wielkiej płyty. Przy czym mieszkania te (rynek wtórny) osiągają ceny porównywalne z nowymi mieszkaniami deweloperskimi. Warto również zwrócić uwagę, że mieszkań przeznaczonych dla seniorów na rynku zarówno wtórnym jak i nowym brakuje. Natomiast w całym mieście wg raportu z 2019 jest tylko jedno, należące do miasta, mieszkanie chronione ${ }^{15}$, jest także 15 legalnie działających do-

\footnotetext{
${ }^{13}$ Autorka artykułu prowadziła badania dotyczące jakości współczesnych budynków deweloperskich

${ }^{14} \mathrm{~W}$ ramach współpracy uzyskano plany, projekty, rzuty, informacje o mieszkańcach oraz przeprowadzano warsztaty z mieszkańcami.

${ }^{15}$ Mieszkanie chronione jest świadczeniem niepieniężnym z pomocy społecznej. Pobyt w takim mieszkaniu może być przyznany osobie, która ze względu na trudną sytuację życiową, wiek, niepełnosprawność albo chorobę potrzebuje wsparcia
} 
mów opieki, domów spokojnej starości, domów pomocy społecznej i domów seniora (Dom opieki). Oferta ta jest niewystarczająca, w związku z czym poszukuje się wolnych miejsc poza granicami miasta. Warto też zwrócić uwagę, że zamieszkanie w domu pomocy społecznej, czy domu opieki w warunkach polskich jest rozwiązaniem ostatecznym, kiedy rodzina nie jest w stanie zaopiekować się takimi osobami. W krajach Europy Zachodniej, przez lata wykształcił się model domów opieki, które są najbardziej powszechną formą zamieszkania osób starych (Magdziak-Grabowska, 2014). Realia polskie nieco odbiegają od tych zachodnich. Należy podkreślić, że nie wszystkie osoby starsze trafią do domów opieki. Są one albo za drogie, albo oferują złe warunki. Większość osób starszych nie chce opuszczać swojego miejsca zamieszkania. W związku z tym powinno się możliwie długo pozostawić ich we własnym środowisku zamieszkania. Tym bardziej, że liczne badania pokazują, iż warunkiem zachowania dobrej kondycji w podeszłym wieku jest między innymi samodzielność. Taką samodzielność zapewnia przede wszystkim własne mieszkanie, o które dbamy, wyposażamy, upiększamy i czujemy się w nim ,jak u siebie".

Przeprowadzone badania obejmują analizę stanu istniejącego osiedla Popowice pod kątem osób starszych i uwzględniają rozwiązania architektoniczne oraz urbanistyczne. Przeprowadzono następujące analizy: urbanistyczno-architektoniczną, morfologii zabudowy, komunikacji, przestrzeni rekreacyjnych i zieleni, infrastruktury technicznej i stanu technicznego budynków, demografii oraz rozwiązania mieszkań. Wyniki analiz, związane z możliwościami funkcjonowania osób starszych w przestrzeni osiedla, zostały zebrane i przedstawione w analizie SWOT. Wnioskiem z badań są dwie propozycje rozwiązań ${ }^{16}$, o charakterze aplikacyjnym, przystosowania osiedla do potrzeb osób starszych, które można uogólnić i przenieść na inne rozwiązania osiedli z wielkiej płyty. Metody badawcze wykorzystane w pracy, polegały na analizach literaturowych, badaniach terenowych, in situ, inwentaryzacji, analizach archiwalnych planów i projektów osiedla, rozmowach fokusowych i warsztatach (Niezabitowska, 2014).

\section{POPOWICE - ANALIZA URBANISTYCZNO-ARCHITEKTONICZNA}

Analizowany obszar położony jest w dzielnicy Fabryczna. Obszar położony jest w pewnej odległości od centrum miasta, 4-5 km od Rynku, znajduje się w bezpośrednim sąsiedztwie trasy wylotowej na Zieloną Górę. Osiedle ogranicza od południa ulica Legnicka, od wschodu ulica Starograniczna i tory kolejowe, od północy ulica Popowicka, a od zachodu ulica Wejherowska. Przedmiotem analizy są nieruchomości o powierzchni 36 ha $(900 \mathrm{~m}$ x $400 \mathrm{~m})$, zamieszkałe przez 15000 osób. Obszar położony jest na zachód od Starego Miasta. Teren sąsiaduje zarówno z osiedlami mieszkaniowymi i terenami handlowo-usługowymi od strony południowej, z terenami rekreacyjnymi od północy, a od strony zachodniej obiektami poprzemysłowymi zaadoptowanymi na różne funkcje. Zabudowa na analizowanym terenie, w wyniku działań wojennych została zrównana z ziemią, w związku z czym projektanci nie musieli wkomponowywać zabudowy w istniejącą tkankę. Osiedle powstało od podstaw na terenie wolnym od zabudowy i w całości składa się z budynków wielorodzinnych oraz budynków obsługujących mieszkańców, tj.: pawilony handlowe, szkoły, przedszkola, kościół (wikipedia).

Duży odsetek w strukturze przestrzennej osiedla zajmują tereny rekreacyjne (przestrzenie półpubliczne) zlokalizowane pomiędzy budynkami. Stosunkowo duży procent stanowią również tereny dróg (publicznych i wewnętrznych), które tworzą dość chaotyczną sieć. Na terenie zauważono dobre wyposażenie w infrastrukturę publiczną (handel, służba zdrowia, sport), która została zlokalizowana w przestrzeniach między budynkami.

Jest to atrakcyjne osiedle, o czym świadczą ceny mieszkań. Pomimo, że są to mieszkania w tzw. po-peerelowskich blokowiskach, średnia cena mieszkania jest niższa tylko o ok. 300-400 zł.(Mieszkania Wrocław) od mieszkań deweloperskich. Zdarzają się również przypadki, gdy ceny

w funkcjonowaniu w codziennym życiu, ale nie wymaga usług w zakresie świadczonym przez jednostkę całodobowej opieki (Dla kogo)

16 Jedna propozycja jest autorskim rozwiązaniem mieszkań, druga została opracowana przez grupę studentów w ramach przedmiotu prowadzonego przez autorkę artykułu. 
są wyższe aniżeli średnia cena mieszkań na rynku wtórnym. Do analizy wybrano mieszkania znajdujące się na badanym osiedlu Popowice.

Tabela 1. Porównanie cen lokali/mieszkań na badanych osiedlach, opracowanie własne na podstawie WGN (opr. własne na podstawie https://adresowo.pl/mieszkania/wroclaw/popowice-l/)

\begin{tabular}{lccll}
\hline Lokalizacja & Wielkość & llość pokoi & Rok budowy & Cena za m2 \\
\hline ul. Popowicka & $54 \mathrm{~m} 2$ & 3 & 1980 & $7375 / 399000$ \\
\hline ul. Białowieska & $34 \mathrm{~m} 2$ & 2 & 1980 & $9700 / 330000$ \\
\hline ul. Wejherowska & $64 \mathrm{~m} 2$ & 3 & 1980 & $7800 / 499000$ \\
\hline ul. Niedźwiedzia & $41.5 \mathrm{~m} 2$ & 2 & 1980 & $8800 / 36500$ \\
\hline ul. Jelenie & $42 \mathrm{~m} 2$ & 2 & 1980 & $9700 / 404000$ \\
\hline
\end{tabular}

Na podstawie powyższej analizy cen mieszkań w obrocie wtórnym można wnioskować, że są one bardzo zbliżone do cen mieszkań w obrocie pierwotnym, a więc mieszkań deweloperskich. W związku z tym należałoby się zastanowić co jest przyczyną takiego „przywiązania” polskiego obywatela do „wielkiej płyty”, skoro powszechne oceny tych osiedli skłaniają do zupełnie odwrotnego sądu.

\subsection{Morfologia zabudowy}

Twórcą osiedla był W. Molicki (M. Molicka, W. Molicki, 2003). W strukturze przestrzennej osiedla dominują tereny zabudowy wielorodzinnej. Są to budynki średniowysokie - 3-5 kondygnacji oraz wysokie - 11 kondygnacji, wykonane w technologii wielkiej płyty, ok. 25 lat temu docieplone. Analizowany fragment jest łatwo dostępny, posiada sieć ścieżek wzdłuż dróg dojazdowych, obsługujących osiedle. Teren badanej części osiedla ma zwarty, prostokątny, wydłużony układ, podzielony ulicami: Rysią, Białowieską i Niedźwiedzią na cztery części (ryc.1) o dość skomplikowanej urbanistyce, spowodowanej ustawieniem budynków nieregularnie, pod różnymi kątami. Taka „łamana” urbanistyka powoduje chaos, który dziś skutkuje m.in. trudnościami w odnalezieniu konkretnych adresów. Budynki zwrócone są balkonami ku południu, a prostymi elewacjami ku północy. Charakterystyczne dla osiedla są skośne, nieregularne balkony, które zrywają z monotonią wielkopłytowej konstrukcji. Układ budynków został tu pomyślany tak, aby każde mieszkanie miało dostateczną ilość światła dziennego. Stąd bloki dzieli spora przestrzeń, która dziś jest dodatkowo cenna zarówno dla dzieci, młodzieży jak i osób starszych.

\subsection{Komunikacja}

Analizowany teren osiedla Popowice jest bardzo dobrze skomunikowany $z$ centrum miasta oraz innymi częściami miasta. Zlokalizowany jest przy głównej drodze wylotowych z Wrocławia, przy których znajduje się rozbudowana sieć komunikacji miejskiej. Dojazd do centrum oraz innych dzielnic miasta zapewniony jest również poprzez komunikację publiczną: autobusową i tramwajową. W niedalekiej odległości znajduje się Dworzec Kolejowy Mikołajów, którego remont został niedawno ukończony oraz Dworzec Popowice, który sąsiaduje z osiedlem, obecnie sporadycznie wykorzystywany, lecz po remoncie ma być częściej użytkowany i będzie m.in. przystankiem szynobusu, który bardzo sprawnie funkcjonuje na terenie aglomeracji miasta ${ }^{17}$.

Osiedle sąsiaduje $z$ dwiema trasami rowerowymi. Jedna poprowadzona jest ulicą Popowicką druga natomiast ulicą Legnicką. Osiedle przecina dodatkowo alternatywna trasa rowerowa. Biegnie ona

17 Transport kolejowy szybkiej kolei miejskiej odgrywa znaczącą rolę, łącząc różne fragmenty miasta z terenami wokół miasta. 
przez środek osiedla, ulica Bobrzą i Jelenią. Wszystkie główne trasy rowerowe poprowadzone są w kierunku wschód-zachód, ograniczona jest liczba tras północ-południe.

W większości przypadków ciągi piesze nie są przystosowane do potrzeb osób niepełnosprawnych oraz starszych: posiadają krawężniki i nierówną nawierzchnię. Jedynie przejścia dla pieszych wykonane są z odpowiednimi obniżeniami, bez krawężników.

Osiedle posiada miejsca postojowe jako wydzielone przestrzenie wzdłuż ulic dojazdowych oraz większe, w formie placów, parkingi wielostanowiskowe. llość miejsc postojowych jest znacznie mniejsza niż potrzeby mieszkańców, szczególnie daje się to odczuć we fragmentach o większej intensywności zabudowy, głównie w sąsiedztwie budynków 11-kondygnacyjnych. Brak wystarczającej ilości miejsc parkingowych skutkuje nieprawidłowym parkowaniem w miejscach do tego nieprzeznaczonych (trawniki, ciągi piesze).

$\mathrm{Na}$ osiedlu znajdują się wydzielone i oznakowane miejsca postojowe przeznaczone dla osób niepełnosprawnych. Najczęściej są one lokalizowane blisko wejść do klatek schodowych.

Nie zauważono natomiast wydzielonych miejsc na rowery, w związku z czym mieszkańcy zostawiają je wszędzie, gdzie jest to możliwe: oparte o drzewa, ławki oraz przed wejściami do klatek schodowych.

\subsection{Przestrzenie rekreacyjne i zieleń}

Charakterystycznym rozwiązaniem osiedli z wielkiej płyty jest duża ilość przestrzeni rekreacyjnych. Analiza terenów pokazuje, że osiedle posiada szereg zróżnicowanych przestrzeni rekreacyjnych (ryc.3) oraz terenów zielonych, wśród nich wyróżnić można:

- tereny w przestrzeniach półpublicznych zlokalizowane pomiędzy budynkami - przestrzenie ogólnodostępne, o charakterze sportowym, wypoczynkowym oraz place zabaw, z których korzystają wszyscy mieszkańcy nawet zamieszkali w odleglejszych fragmentach.

- tereny w przestrzeniach publicznych - zlokalizowane przeważnie poza granicami osiedla, w odległości ok. $800 \mathrm{~m}$ od miejsca zamieszkania. Należą do nich tereny ogólnodostępne w formie parków i skwerów, tj. Park Zachodni, Park Popowicki oraz skwer przy kościele.

Tereny zabaw utrzymane są w dobrym stanie. Większość z nich przeszła generalną modernizację, sprzęt wymieniono na nowy, w związku z czym są kolorowe i różnorodne. W przestrzeniach pomiędzy budynkami znajdują się również tereny sportowe, o szerokiej ofercie np.: korty tenisowe, boiska do koszykówki i siatkówki, a także górka crossowa przy ulicy Rysiej.

$\mathrm{Na}$ osiedlu znajduje się wiele miejsc do wypoczynku (ławki, siedziska), które są szczególnie istotne dla osób starszych, korzystających z biernej formy rekreacji.

Osiedle posiada bardzo bogatą roślinność, z reguły są to dorosłe, wysokie drzewa oraz krzewy. Stan zadbania jest bardzo zróżnicowany i zależy od fragmentu, do którego należy. Podobnie sytuacja prezentuje się z ciągami pieszymi, którymi osiedle bardzo licznie jest poprzecinane w kierunku północno-południowym oraz wschodnio-zachodnim. Jakość ciągów pieszych oraz dostosowanie do potrzeb osób starszych, podobnie jak zieleni jest zróżnicowana. Budynki posiadają przy wejściach przedogródki, które są zaniedbane z przypadkową roślinnością. Natomiast przy balkonach mieszkańcy organizują prywatne zielone przestrzenie $z$ bardzo ładną szatą roślinną.

\subsection{Infrastruktura społeczna}

Ważnym aspektem prowadzonych analiz w kontekście osób starszych jest infrastruktura społeczna. Osiedle Popowice posiada dużą liczbę usług zlokalizowanych na terenie oraz w bezpośrednim sąsiedztwie. Analizując infrastrukturę społeczną osiedla należy stwierdzić, że:

- osiedle jest dobrze wyposażone w szereg obiektów, szczególnie oświatowych, które mogą być wykorzystywane przez osoby starsze, np. sale gimnastyczne, basen w szkole.

- duża jest ilość usług handlowych. 
- osiedle znajduje się w sąsiedztwie SEKTORA 318, w ramach którego działa Fundacja Aktywny Senior, z którego mogą korzystać i korzystają starsi mieszkańcy osiedla.

- brakuje usług gastronomicznych, aby z nich skorzystać należy odbyć długą drogę w inne rejony osiedla.

- nie wszystkie usługi są dostępne dla osób starszych i niepełnosprawnych. Część lokali usługowych znajduje się na wyższych kondygnacjach, które obsługiwane są tylko za pomocą schodów (brak ramp, wind, platform).

\subsection{Stan techniczny budynków}

Stan techniczny budynków można określić jako średni. Budynki mieszkalne wykonane zostały w technologii Wrocławskiej Wielkiej Płyty:

- wszystkie budynki wyposażone są w ogrzewanie z sieci miejskiej - c.o., wodę oraz gaz.

- część mieszkań posiada klimatyzację. Są to jednak prywatne inwestycje, w związku z czym urządzenia klimatyzacyjne montowane są na balkonach lub elewacjach, burząc czystość elewacji.

- budynki 5-kondygnacje nie posiadają wind, natomiast wyższe, 11-kondygnacyjne wyposażone są w windy.

- budynki przeszły termomodernizację dość dawno i docieplono je tylko $5 \mathrm{~cm}$ warstwą styropianu.

- odnowiono kolorystykę oraz docieplono ściany szczytowe w nowej odsłonie graficznej, il. 2.

- w większości mieszkań lokatorzy wymienili okna na nowe, niekoniecznie zgodnie z pierwotnymi podziałami.

- balkony znajdują się w bardzo złym stanie, tynki - przez lata narażone na czynniki atmosferyczne - posiadają spękania i ubytki.

- część wejść do klatek schodowych nie jest dostępna dla osób niepełnosprawnych, ponieważ występują progi oraz schodki.

\subsection{Rozwiązania mieszkań}

Osiedle oferuje zróżnicowane powierzchniowo mieszkania od 1-pokojowych do mieszkań 5-pokojowych ${ }^{19}$. Na osiedlu znajdują się 2 typy budynków: 11-kodygnacyjne klatkowe oraz 5-kondygnacyjne klatkowe z 2 lub 3 mieszkaniami na kondygnacji. Budynki rozwiązano poprzez różną konfigurację kilku typów mieszkań oraz wprowadzanie zmiennej ilości segmentów (klatek schodowych). Pomimo tego, że osiedle zostało zaprojektowane i wybudowane $w$ technologii uprzemysłowionej struktura mieszkań jest zróżnicowana. Na każdej kondygnacji znajdują się dwa lub trzy mieszkania. Na osiedlu wyszczególnić można następujące wielkości mieszkań dużych, które składają się z pokoi, kuchni, holu, łazienki i wc ${ }^{20}$ :

- 1 mieszkanie 5-pokojowe 37 - 78,80 m2

- mieszkania 3-pokojowe o różnych powierzchniach - 50,50 m2, 53,50 m2, 57 m2, 58 m2, 59,50 $\mathrm{m} 2$ i $65,50 \mathrm{~m} 2$

- mieszkania 4-pokojowe o powierzchni $63 \mathrm{~m} 2$

Do mieszkań średniej wielkości zaliczyć możemy:

- mieszkania 2-pokojowe o powierzchni: 49,50 m2 i 50,50 m2

Natomiast do mieszkań małych:

\footnotetext{
${ }^{18}$ Wrocławskie Centrum Wspierania Organizacji Pozarządowych Sektor 3 działa od kwietnia 2007 roku. Prowadzone jest przez Fundację Wspierania Organizacji Pozarządowych "UMBRELLA” w formie zadania publicznego i jest finansowane z budżetu Gminy Wrocław. W okresie 1 stycznia 2020 - 31 grudnia 2022 realizujemy projekt „Prowadzenie Wrocławskiego Centrum Wspierania Organizacji Pozarządowych Sektor 3". (O centrum)

${ }^{19} \mathrm{Na}$ osiedlu znajduje się tylko jedno takie mieszkanie, które powstało z połączenia dwóch mieszkań.

${ }^{20}$ Dane uzyskane od zarządcy spółdzielni.
} 
- mieszkania 2-pokojowe o powierzchni: 41,50 m2, 41 m2, 40,50 m2, 39 m2 i 33 m2

- mieszkania 1-pokojowe o powierzchni 23,50 m2

Mieszkania posiadają pokoje dzienne o podobnej wielkości ok. $14,50 \mathrm{~m}^{2}$, biorąc zatem pod uwagę obecne przepisy (Rozporządzenie...), są to wielkości nie spełniające współczesnych przepisów ${ }^{21}$, sypialnie posiadają minimalne wielkości od 7 do $9 \mathrm{~m}^{2}$. Większe mieszkania posiadają łazienki oraz niezależne wc.

\subsection{Demografia}

Z uzyskanych materiałów oraz badań wynika, że dość duży odsetek mieszkańców stanowią osoby powyżej 60 roku życia. W tej części stanowią ok. $70 \%{ }^{22}$. Są to osoby, które zamieszkują osiedle od początku jego powstania. Wprowadzili się do mieszkań jako młode małżeństwa i pozostali w nich do dzisiaj. Na początku XXI wieku, po roku 2006. pojawiło się dość dużo osób młodych. Związane było to $z$ uruchomieniem nowego programu finansowego RnS. Wchodzący w życie program umożliwiał uzyskać rodzinom preferencyjne kredyty. W tym okresie wiele osób młodych kupiło na osiedlu mieszkania, które były stosunkowo nieduże (niedrogie), a bliskość terenów rekreacyjnych i usług oświatowych sprawiała, że miejsce to było i jest nadal idealne dla młodych małżeństw z dziećmi. Są one widoczne na terenach rekreacyjnych.

\section{SENIORZY W PRZESTRZENI OSIEDLA POPOWICE - WNIOSKI Z ANALIZ}

Po przeprowadzeniu analiz stanu istniejącego nasuwają się wnioski, które zostały zawarte w formie analizy SWOT w tab. 2. Związane są one z możliwościami funkcjonowania osób starszych, w tym niepełnosprawnych w przestrzeni osiedla

Tabela 5. Analiza SWOT badanych osiedli z wielkiej płyty pod kątem dostosowania do potrzeb osób starych, (źródło: opr. własne)

\begin{tabular}{|c|c|c|}
\hline \multirow[b]{2}{*}{ urbanistyczne } & \multicolumn{2}{|l|}{ Mocne strony (strengths) } \\
\hline & architektoniczno-techniczne & społeczno-ekonomiczne \\
\hline $\begin{array}{l}\text { Dobre powiązania komunikacyjne } z \\
\text { miastem }\end{array}$ & $\begin{array}{l}\text { Wyposażenie mieszkań w instalacje } \\
\text { techniczne }\end{array}$ & Stosunkowo niskie koszty eksploatacji \\
\hline Duża ilość usług podstawowych & $\begin{array}{l}\text { Rozwiązanie funkcjonalne mieszkań - } \\
\text { rozkładowe }\end{array}$ & $\begin{array}{l}\text { Znajomość sąsiadów i zaciśnięte więzi } \\
\text { sąsiedzkie }\end{array}$ \\
\hline $\begin{array}{l}\text { Bliskość terenów rekreacyjnych i } \\
\text { sportowych }\end{array}$ & $\begin{array}{l}\text { Wielkości mieszkań - z reguły odpowied- } \\
\text { nia dla małżeństw bądź osób samotnych } \\
\text { (2 i 3-pokojowe) }\end{array}$ & $\begin{array}{l}\text { Możliwość dofinansowania z funduszy } \\
\text { unijnych }\end{array}$ \\
\hline \multicolumn{3}{|l|}{ Duża ilość zieleni } \\
\hline \multicolumn{3}{|l|}{ Znaczna ilość przestrzeni } \\
\hline \multicolumn{3}{|l|}{ Dobra infrastruktura osiedlowa } \\
\hline & \multicolumn{2}{|l|}{ Słabe strony (weaknesses) } \\
\hline & $\begin{array}{l}\text { Klatki schodowe w budynkach } 5 \text { - } \\
\text { kondygnacyjnych bez wind }\end{array}$ & $\begin{array}{l}\text { Brak środków finansowych na remonty i } \\
\text { modernizacje }\end{array}$ \\
\hline $\begin{array}{l}\text { Brak rozwiązanej komunikacji } \\
\text { rowerowej }\end{array}$ & $\begin{array}{l}\text { Wejścia do klatek schodowych bez pod- } \\
\text { jazdów, pochylni - bariery }\end{array}$ & Uciekanie młodych z tego typu osiedli \\
\hline $\begin{array}{l}\text { Brak wystarczającej ilości miejsc } \\
\text { postojowych }\end{array}$ & $\begin{array}{l}\text { Brak przy wejściach do klatek schodo- } \\
\text { wych miejsc do siedzenia oraz na rowery }\end{array}$ & $\begin{array}{l}\text { Przyzwyczajenie do miejsca zamiesz- } \\
\text { kania }\end{array}$ \\
\hline
\end{tabular}

\footnotetext{
${ }^{21} \S 94$, pkt 2. W mieszkaniu co najmniej jeden pokój powinien mieć powierzchnię nie mniejszą niż $16 m^{2}$ (Rozporządzenie)

${ }^{22}$ Dane spółdzielni zarządzającej osiedlem
} 


\begin{tabular}{|c|c|c|}
\hline $\begin{array}{l}\text { Brak wystarczającej liczby wydzie- } \\
\text { lonych miejsc postojowych dla } \\
\text { osób niepełnosprawnych }\end{array}$ & $\begin{array}{l}\text { Mieszkania nieprzystosowane dla osób } \\
\text { niepełnosprawnych (na wózkach) }\end{array}$ & $\begin{array}{l}\text { Osiedla zamieszkiwane głównie przez } \\
\text { osoby starsze }\end{array}$ \\
\hline \multirow[t]{3}{*}{ Zieleń o różnym stanie zadbania } & $\begin{array}{l}\text { Brak w budynkach przestrzeni wspólno- } \\
\text { towych }\end{array}$ & $\begin{array}{l}\text { Wynajmowanie mieszkań czasowo - } \\
\text { studentom }\end{array}$ \\
\hline & Brak prywatnych ogródków & \\
\hline & Szanse (opportunities) & \\
\hline $\begin{array}{l}\text { Sprzyjające osobom starym śro- } \\
\text { dowisko mieszkaniowe }\end{array}$ & $\begin{array}{l}\text { Mieszkania przystosowane dla osób } \\
\text { starszych - po modernizacji }\end{array}$ & $\begin{array}{l}\text { Uzyskanie dofinansowanie ze środków } \\
\text { unijnych, miejskich bądź projektów } \\
\text { celowych }\end{array}$ \\
\hline \multirow[t]{2}{*}{$\begin{array}{l}\text { Dogęszczenie zabudowy budyn- } \\
\text { kami przeznaczonymi dla osób } \\
\text { starych }\end{array}$} & $\begin{array}{l}\text { Udostępnienie mieszkań na wyższych } \\
\text { kondygnacjach poprzez budowę wind } \\
\text { oraz platform i ramp. }\end{array}$ & \\
\hline & Zagrożenia (threats) & \\
\hline $\begin{array}{l}\text { Wprowadzenie na teren osiedli } \\
\text { budynków deweloperskich (osiedla } \\
\text { grodzone) może w niekontrolowany } \\
\text { sposób zagęścić zabudowę }\end{array}$ & $\begin{array}{l}\text { Budynki bez remontów i dostosowania ich } \\
\text { do zmieniających się potrzeb będą podu- } \\
\text { padać i marnieć }\end{array}$ & $\begin{array}{l}\text { Osamotnienie spowodowane brakiem } \\
\text { kontaktów z otoczeniem (bariery) }\end{array}$ \\
\hline $\begin{array}{l}\text { Nowe inwestycje kosztem prze- } \\
\text { strzeni społecznych mogą zdewa- } \\
\text { luować tereny rekreacyjne, spor- } \\
\text { towe, zabaw }\end{array}$ & & $\begin{array}{l}\text { Osiedla mogą stać się slumsami za- } \\
\text { mieszkałymi przez najniższe grupy } \\
\text { społeczne }\end{array}$ \\
\hline
\end{tabular}

Z analiz wynika, że przestrzeń zewnętrzna osiedla przy drobnych działaniach naprawczych jest w zadawalającym stanie $w$ odniesieniu do potrzeb osób starszych. W trakcie badań przeprowadzono również spotkania/warsztaty z seniorami zamieszkującymi osiedle oraz rozmowy fokusowe w wyniku których mieszkańcy wypowiedzieli się na temat sposobu i formy zamieszkania w przypadku pełnej lub częściowej utraty samodzielności. Wynik tych badań nie stanowił zaskoczenia, ponieważ wszyscy opowiedzieli się pozostaniem w obecnym miejscu zamieszkania, potrzebowaliby jedynie wsparcia z zewnątrz w codziennych aktywnościach. Natomiast w przypadku poważniejszej niepełnosprawności chcieliby pozostać w środowisku, które znają czyli w przestrzeni osiedla, ale w innym obiekcie, np. domu seniora ulokowanym w sąsiedztwie miejsca zamieszkania.

W związku z tym zaproponowano dwa rozwiązania:

- Przekształcenie mieszkań do potrzeb osób starszych w tym niepełnosprawnych.

- Przekształcenie jednego $z$ budynków na dom seniora.

\subsection{Przekształcenie mieszkań do potrzeb osób starszych w tym niepełnosprawnych.}

Analizy istniejącej zabudowy jak i innych osiedli/budynków, które przeszły gruntowną modernizacją pokazują, że istnieje możliwość przebudowy zarówno klatek, jak i mieszkań w celu udostępnienia ich osobom starszym, w tym niepełnosprawnym. Najmniej kosztochłonne rozwiązanie da się zastosować w przypadku budynków wysokich 11-kondygnacyjnych, które są już dziś wyposażone w windy, których bieg, niestety rozpoczyna się od pierwszej kondygnacji. Proste rozwiązanie może stanowić ruchoma platforma łącząca przyziemie z pierwszą kondygnacją. Znacznie bardziej skomplikowane rozwiązania należałoby wprowadzać do budynków 5-kondygnacyjnych, które wind nie posiadają. Jedyną możliwością jest przebudowa klatek schodowych, tak aby wprowadzić niezależne windy.

Najważniejszą kwestią jest jednak dostosowanie mieszkań do potrzeb osób starszych, w tym niepełnosprawnych. Systemy konstrukcyjne zastosowane przy budowie, umożliwiają drobne przesunięcia ścian oraz pewne przebudowy układów funkcjonalnych. W pierwszej kolejności należy dostosować łazienki oraz toalety poprzez ich powiększenie. W grę wchodzi również łączenie łazienek z toaletami w celu osiągnięcia większej przestrzeni manewrowej. Ważne jest poprawne rozwiąza- 
nie kuchni, poprzez odpowiednią aranżację umeblowania oraz stworzenia przestrzeni manewrowej. Ilustracja pokazuje przykładowe rozwiązanie wnętrza mieszkalnego przystosowanego do potrzeb osoby niepełnosprawnej.

\subsection{Przekształcenie jednego $z$ budynków na dom seniora}

W odpowiedzi na powyższe wnioski w rozdziale tym przedstawiono studencką propozycję przekształcenia jednego z budynków 11-kondygnacyjnych na „dom seniora”. Założeniami projektowymi była modernizacja istniejącego budynku i dostosowanie go do potrzeb osób starszych $(70+)^{23}$, Autorzy zaprezentowali 8 zróżnicowanych funkcjonalnie modułów wspólnotowych o powierzchni $115 \mathrm{~m}^{2}$, (ryc. 6).

W podobny modułowy sposób zostały rozwiązane mieszkania, które mają zaspakajać podstawowe potrzeby mieszkalne. Zaprojektowano zatem mieszkania jedno-, dwu- i trzypokojowe, wszystkie zaopatrzone w logie lub balkony. Mieszkania celowo nie są duże, ponieważ wiele aktywności, tj.; praca, spotkania towarzyskie, gotowanie, powinno odbywać się w przestrzeniach wspólnych. Część usługowa, sklepy, kawiarnie, rehabilitacja, tradycyjnie znajduje się w parterze i dostępne są z ulicy. Elewacje rozwiązane zostały jako powtarzalna struktura, przerwana mocnymi akcentami przeszklonych, kolorowych płaszczyzn, za którymi kryją się przestrzenie wspólne. Ten zabieg sprawił, że pomimo powtarzalności elewacje nie są nudne, (ryc. 7).

\section{WNIOSKI}

Przy pewnych nakładach finansowych, istnieje możliwość poprawy jakości zamieszkania, które może być przeprowadzona poprzez szereg działań ułatwiających życie i funkcjonowanie osób starszych, w tym niepełnosprawnych. Działania te można podzielić na kilka grup:

- Dostosowanie - m.in. mieszkań do nowych potrzeb

- Adaptacja - budynków na domy z przeznaczeniem dla seniorów

- Intensyfikacja - wprowadzanie dziennych i całodobowych ośrodków senioralnych

- Cohousing - zagospodarowanie niewykorzystanych pomieszczeń na wspólne przestrzenie ukierunkowane na potrzeby osób starszych.

Reasumując przedstawione badania w kontekście spełnienia kryteriów dostosowania do osób starszych i niepełnosprawnych najwyżej ocenić można przestrzenie osiedla, które są w największym stopniu dostosowane do potrzeb tej grupy społecznej. Warto dodać, że osiedla są otoczone zielenią oraz posiadają szereg budynków usługowych, które w dużym procencie są dostępne dla osób starszych oraz skierowane na zaspakajanie ich potrzeb. Na drugim miejscu znajduje się transport publiczny. Jest on w dużym stopniu zależny od polityki władz miasta, a w badanych lokalizacjach rozwiązany jest stosunkowo poprawnie. Najgorzej prezentuje się rozwiązanie mieszkań, które nie są dostosowane do potrzeb osób starszych. Natomiast istnieje realna możliwość przeprowadzenia działań naprawczych, zmierzających do dostosowania osiedli do potrzeb osób starszych, w tym niepełnosprawnych. Ważna jest jednak szeroka współpraca ośrodków senioralnych, zarządców jak i władz miasta.

\footnotetext{
${ }^{23}$ Projekt zrealizowany w ramach przedmiotu wybieralnego - Projektowanie dla osób starszych. Autorzy: Paweł Floryn, Łukasz Sokołowski, opiekun - Barbara Gronostajska.
} 


\section{BIBLIOGRAPHY}

Dla kogo mieszkania chronione? www.niepelnosprawni.pl/ledge/x/27901 dostęp/access 20.10.2020

Domy opieki Wrocław. https://domyopieki.pl/miasta/Wroc\%C5\%82aw/ dostęp/access 20.10.2020

Gehl J. Miasta dla ludzi, Wydawnictwo RAM, Kraków 2014.

Gospodarstwa domowe i rodziny, GUS, Warszawa, 2002.

Gronostajska B. Projektowanie dla seniorów, Oficyna Wydawnicza Politechniki Wrocławskiej, Wrocław, 2016.

Gyurkovich J, Architektura w przestrzeni miasta. Wybrane problemy, Wydawnictwo Politechniki Krakowskiej, 2010

Jałowiecki B, Szczepański M., Miasto i przestrzeń w perspektywie socjologicznej, Wydawnictwo Naukowe Scholar, Warszawa 2006.

Kobylarczyk, J., Uwarunkowania środowiskowe w projektowaniu obszarów mieszkaniowych, Wydawnictwo Politechniki Krakowskiej., 2018

Komar B., Współczesna jakość spółdzielczej przestrzeni osiedlowej w świetle zasad zrównowaonego rozwoju, Wydawnictwo Politechniki Śląskiej, Gliwice 2014

Ludność Polski. https://pl.wikipedia.org/wiki/Ludno\%C5\%9B\%C4\%87_Polski

Mieszkania Wrocław Popowice https://adresowo.pl/mieszkania/wroclaw/popowice-l/ dostęp/access 15.10.2020

Molicka M. Molicki W. Maria Molicka, Witold Molicki, Wydawnictwo: Muzeum Architektury we Wrocławiu, SARP Wrocław, Wrocław, 2003,

Niezabitowska E. D., Metody i techniki badawcze w architekturze, Wydawnictwo Politechniki Śląskiej, Gliwice, 2014.

O centrum http://www.sektor3.wroclaw.pl/) dostęp/access 23.09.2020

Pallado, J., Architektura wielorodzinnych domów dostępnych, Wydawnictwo Śląsk, Katowice, 2007.

Popowice. https://pl.wikipedia.org/wiki/Popowice_(Wroc\%C5\%82aw) dostęp/access 20.09.2020

Ranking "Miasta seniorów". Czy Wrocław jest dla długowiecznych? https://wroclaw.wyborcza.pl/wroclaw/7,35771,23917837,ranking-miasta-seniorow-czy-wroclaw-jest-dladlugowiecznych.html dostęp/access 11.08.2019

Raport o stanie Wrocławia za rok 2019 https://www.wroclaw.pl/portal/raport-o-stanie-wroclawia-za-rok-2019 dostęp/access 25.09.2020

Rocznik Statystyczny woj. dolnośląskiego rok 1988, Wydawnictwo Urzędu Statystycznego, Wrocław, 1988

Rocznik Statystyczny woj. dolnośląskiego rok 2004, Wydawnictwo Urzędu Statystycznego, Wrocław, 2004

Rozporządzenie Ministra Infrastruktury w sprawie warunków technicznych, jakim powinny odpowiadać budyn$\mathrm{ki}$ i ich usytuowanie wraz z zmianami / Ordinance of the Minister of Infrastructure concerning the technical conditions to be met by buildings and their placement, as amended

Tulkowska-Słyk, K., Nowoczesne mieszkanie, Warszawa: Oficyna Wydawnicza Politechniki Warszawskiej, 2019.

Wojtkun G., Osiedla Kaliny i Przyjaźń w Szczecinie - „uniwersalna” wielorodzinna zabudowa mieszkaniowa, Przestrzeń i forma no 16, s. 609-622. Wyd. SFERA. 2011

Wrocław: Popowice będą bardziej kolorowe. https://dolnoslaskie.naszemiasto.pl/wroclaw-popowice-bedabardziej-kolorowe/ga/c4-1368157/zd/2467573, dostęp/access 25.10.2020

Zaniewska H, Thiel M., Mieszkaniowe obszary problemowe w Polsce - identyfikacja cech architektonicznoprzestrzennych, Architectuare at Artibus, 1/2009.

Ziobrowski Z., opinia do Studium uwarunkowań i kierunków zagospodarowania przestrzennego gminy, Wrocław 2000 Plus, Studia nad strategią miasta. Biuro Rozwoju Wrocławia, z. 9, Wrocław, 1997. 


\section{AUTHOR'S NOTE}

Barbara E. Gronostajska, professor at the Department of Architectural and Structural Design at the Wrocław University of Science and Technology, deputy head of the Department, Dean of the Faculty of Architecture, Wrocław University of Science and Technology. In her research activity she deals with the issues of universal design, shaping the environment for the elderly, modernization of large-panel housing estates and pro-ecological architecture.

\section{O AUTORZE}

Barbara E. Gronostajska, profesor w Katedrze Projektowania Architektoniczno-Konstrukcyjnego WA Politechniki Wrocławskiej, zastępca kierownika Katedry, Dziekan Wydziału Architektury PWr. W swojej działalności naukowej zajmuje się zagadnieniami projektowania uniwersalnego, kształtowania środowiska dla osób starszych, modernizacją budynków z wielkiej płyty oraz architekturą proekologiczną.

Contact | Kontakt: barbara.gronostajska@pwr.edu.pl 